\title{
STAT I
}

\section{INTRODUCTION TO OPEN TECHNOLOGY INNOVATION STRATEGIES}

\author{
Marek Jemala*
}

\section{Introduction}

Approximately since the time of Adam Smith and his "innovation by working men", the open innovation approach can be seen more and more in many different forms and industries. Overall national, sectoral and regional attractiveness as well as quality of know-how, skills, supportive legislation and taxes have become the main factors for relocation of participative R\&D and other business activities over the years. In addition, suitable structural and regional policies, good public infrastructure, and highly skilled workforces can be considered other significant determinants. But willingness and possibility to link and multiply business activities in a region or industry have required new forms of business strategies, structures and innovative attitudes. Traditional, relatively closed business strategies have usually led companies to assume more or less defensive positions against the external environment as well as restricted internal strengths of institutions that might have been multiplied through open business cooperation (Chesbrough and Appleyard, 2007).

Besides, over the years, companies have usually gained better impulses for innovation and business from the external environment. For example, Procter and Gamble has obtained about 35\% of its new product inventions from the external environment in the last 5 years and is about to increase this number to about $50 \%$ soon. This has been realized by about 80,000 on-line independent experts working under the auspices of InnoCentive Group Inc. (CED, 2006). As another example, Philips has recently invited about 7,000 people from different backgrounds for the same reason (Chesbrough and Garman, 2009). This trend can be seen in many other companies all over the world. More and more new business models are applied, such as the Open innovation strategy, Open networks, Open platforms, Open communities,

* University of Economics in Bratislava, Faculty of Business Management (marek.jemala@euba.sk). 
Ecosystems etc. (Chesbrough, 2006). These all should bring better strategic synergies with higher profits, values added and effectiveness in a value chain in which more and more intensive coopetition is usually created.

The key business attitude in many industries and, let us say the key issue regarding open innovation strategy at the same time, is towards strategic opening-up of companies to wider sharing of information, know-how, resources and other inputs as well as more intensive cooperation even with competitors or substitutors. This open business strategy should create a complementary synergic business environment where external partners, customers or other stakeholders are more deeply involved in an innovation process but also in other processes in a company, e.g., training, financing, marketing, technical or technological support, and thus enable creation of more complex and less risky business solutions. The OI strategy must enable increasing cooperation among different partners and their R\&D activities by greater use of common know-how and resources (Jusko, 2009). Generally, every new member of a group should enhance the synergy of openness in two ways. Every new member should contribute to the synergic value creation by its own resources and know-how to a certain level of effective group manageability and by avoiding sub-optimal outcomes/biases of the cooperation. Secondly, more members of the cooperation, better momentum behind innovation, processes, technologies and market power, and usually more akin to a public good (Chesbrough and Appleyard, 2007). Thus, the main benefit can be a more complex base of information, know-how and other capacities for innovation processes based on a selected form of OI strategy. Companies can choose different forms of how to open their innovation strategies, such as partnerships with external parties (business alliances, joint ventures, joint R\&D), acquisitions, contractual $\mathrm{R} \& \mathrm{D}$, purchasing of patents, licensing, etc. In addition to these common forms, an OI strategy can be realized through spin-offs or venture capital investment funds too.

However, any selection of one of these forms of open cooperation should be interconnected with an appropriate change in management. Managerial processes in extensive open business networks usually require very good coordination and establishment of specific network boards. Based on the research, there is usually a curvilinear $U$-shaped relationship between board continuity and innovation performance (Wincent et al., 2009). If there is lower board continuity, this can usually facilitate individual needs of new board members, but also spur innovation processes by delivering fresh ideas or by enhancing mutual learning. Besides, a change in management is often required so as to stop less successful projects. It is also possible to identify new perspectives or synergies within the existing cooperation. On the other hand, boards with higher durability are more likely to become more cohesive, more efficient and have higher trust built over the time. Thus, the board continuity and the management style may be a significant factor for improvement in the innovation potential of open innovation networks (Wincent et al., 2009). However, the long-term sustaining of these issues requires an appropriate mix of open cooperation and appropriate self-organizing of each member involved. Appropriate consideration and design of this change that affects overall open innovation synergies is the significant issue in these processes. 
In general, there are at least three determinants to an OI strategy. The first one, the best ideas for innovation, usually comes from outside a company, e.g., customers and broader expert discussion that is not usually part of an internal management process. This fact may be strengthened by effective marketing as well as by business participation in a regional or industrial foresight process. Secondly, due to their business effectiveness, companies usually perform their core activities around their main business and outsource what somebody else can do better and more effectively. Here, it is already necessary to consider very sensitively what may be outsourced so as not to imperil the core business know-how. In the third place, companies increasingly use new forms of searching for inventions outside, e.g., through patent and bibliometric analyses, new social networking technologies, the Internet, etc.

Based on an extensive literature review and many discussions with different experts, this article identifies the main drivers, key barriers and successful factors, main questions, and basic typology of OI strategies in general. The issue of global innovation networks as a new phenomenon in these circumstances in recent years is outlined at the end of the article.

\section{Main drivers behind open technology innovation strategy}

More and more companies perform intensive technology marketing and selling of their own technologies which usually become another diversification of their business portfolios. It is known that outward technology transfer based on outlicensing has been applied in many companies for a long time. However, both these processes may not necessarily already constitute an OI strategy. Both these attitudes are externally orientated and, first and foremost, both must be based on a very good technology planning process. Many companies usually act "ad hoc" towards external technology exploitation and what they usually miss is the appropriate strategic technology foresight (Lichtenthaler, 2008). This foresight often includes integrated planning instruments in order to consider both technology and product orientated aspects (Groenveld, 1997). Technology planning should include various kinds of foresight methods (Key technologies, Roadmapping, Delphi, Expert panels, Simulation and Modelling, etc.), which enable finding out more complex future solutions, drivers as well as possible risks over a very long period of time. These have many implications for the effectiveness of technological processes, but mainly for better economic results of a company. Traditional foresight methods like scenarios or product roadmaps are often focused on product markets, that is, on internal technology exploitation. For open technology management, the most effective way is to apply different combinations of planning methods, such as SWOT analysis - Expert panels - Key technologies, SWOT - Forecasts - Simulations and Modelling, or Bibliometric and Patent analysis - SWOT - Roadmapping, etc. All applied methods must be fully integrated with conventional strategic planning. What is required in the context of $\mathrm{OI}$ is to keep implementing technological objectives into the main business strategy and thus to prepare technological capacities for the realization of the OI strategy. This kind of strategy has several main drivers. 
Some of the main drivers behind an OI strategy:

- Better ideas for better innovation are usually found outside a company.

- Outsourcing and multisourcing (outside-in, but also inside-out) play an important role for higher effectiveness and openness of innovation processes in many companies.

- Companies increasingly use new forms of searching for inventions outside, e.g., through patent and bibliometric analyses, new social networking technologies, Internet searches, etc.

- Global talent mobility affected by globalisation acts as a new source of human capacities, but also new forms of education and working (e-learning, e-business, etc.).

- Increases in VC affected by the rise in prices of many primary materials.

- Increases in governmental or international spending enabling small companies to innovate more intensively or participate in larger R\&D projects.

- More complex focus of R\&D due to the more complex dynamics of the environment.

- Emergence of private research business.

- Advancement of Internet and logistic technologies.

- The need to optimise existing supplier/consumer networks for higher synergic value.

- Push for commercial applications by government labs (Chesbrough, 2003).

- The role of venture capital has significantly increased recently, which enables promising ideas and technologies to be developed outside a company (Bughin et al., 2008).

- There are better opportunities for further development of ideas and technologies outside a company, for instance by spin-offs, outlicensing, and technology transfer or through other licensing agreements.

- Stakeholders and mainly customers, suppliers, investors, environmental organizations play a more important role in the innovation process.

The open innovation strategy should enable information, know-how or other resources to move relatively freely in and out of an organization. In general, there is the inbound flow called outside-in open innovation that can foster internal capabilities (e.g., technology transfer, outsourcing, licensing, etc.). This approach is more common. An inside-out open innovation approach can be more helpful specifically in these lean economic times in order to diversify business investment. Small introductory investment outside a company may bring a reduction in costs related to the bigger uncertainty at the beginning of a project. For the inside-out approach, we can formulate several main open innovation moves such as making small introductory investment, becoming a stakeholder in a company's former internal project, developing non-strategic initiatives by others, making IP work better, growing own ecosystem, creating open domains to reduce costs and increase participation; see Table 1 (Chesbrough and Garman, 2009). 
Table 1

Main open innovation moves (inside-out)

\begin{tabular}{|l|l|l|l|l|l|l|}
\hline $\begin{array}{l}\text { Main OI } \\
\text { moves }\end{array}$ & $\begin{array}{l}\text { Making small } \\
\text { introductory } \\
\text { investment }\end{array}$ & $\begin{array}{l}\text { Becoming a } \\
\text { stakeholder } \\
\text { in a } \\
\text { company's } \\
\text { former } \\
\text { internal } \\
\text { project }\end{array}$ & $\begin{array}{l}\text { Developing } \\
\text { non-strategic } \\
\text { initiatives by } \\
\text { others }\end{array}$ & $\begin{array}{l}\text { Making IP } \\
\text { work better }\end{array}$ & $\begin{array}{l}\text { Growing } \\
\text { own } \\
\text { ecosystem }\end{array}$ & $\begin{array}{l}\text { Creating open } \\
\text { domains to } \\
\text { reduce costs } \\
\text { and increase } \\
\text { participation }\end{array}$ \\
\hline If & $\begin{array}{l}\text { There is } \\
\text { bigger } \\
\text { uncertainty } \\
\text { at the } \\
\text { beginning } \\
\text { of a project. }\end{array}$ & $\begin{array}{l}\text { Bigger new } \\
\text { capacity } \\
\text { than a } \\
\text { company } \\
\text { possesses is } \\
\text { required. }\end{array}$ & $\begin{array}{l}\text { A company } \\
\text { refocuses } \\
\text { its activities } \\
\text { because of } \\
\text { much spare } \\
\text { effort, time } \\
\text { and capital } \\
\text { invested in } \\
\text { non-strategic } \\
\text { initiatives. }\end{array}$ & $\begin{array}{l}\text { IP does not } \\
\text { generate } \\
\text { appropriate } \\
\text { benefits and } \\
\text { expected } \\
\text { outcomes. }\end{array}$ & $\begin{array}{l}\text { A company } \\
\text { innovates } \\
\text { intensively } \\
\text { and openly; } \\
\text { there is } \\
\text { appropriate } \\
\text { business } \\
\text { environ- } \\
\text { ment. }\end{array}$ & $\begin{array}{l}\text { Know-how, } \\
\text { resources and } \\
\text { information } \\
\text { canterest } \\
\text { of others } \\
\text { and can be } \\
\text { multiplied by } \\
\text { broader open } \\
\text { cooperation. }\end{array}$ \\
\hline
\end{tabular}

Source: Corrected based on Chesbrough and Garman, 2009.

\section{Several main barriers and successful factors to open technology innovation strategy}

At the business level, we can recognize several main barriers and success factors to an OI strategy. Based on my study, these barriers and merits have at least four interconnected areas of origin. The first one is the current and expected financial situation of a company. The second one is the nature of the business and intensity of competition. The third one is dissimilarity in product ranges and the type of technology used. Finally, the fourth area is the management style and managerial willingness to take risks.

Any change of technology can be a financially as well as managerially very demanding process. Therefore, before applying an OI strategy, first of all the company has to analyse its current and expected financial situation. Can we afford it? How much will it be? For example, Lucent, IBM or Dow Chemicals earn much more than USD 100 million a year on outlicensing (Lichtenthaler, 2008). The IBM licensing income is about USD 1 billion, but it spends about USD 6 billion on R\&D every year (Chesbrough and Garman, 2009). Companies usually have to invest a lot and enter into more than one outlicensing agreement. Here, it is necessary to establish the already mentioned integrated management in order to manage several new organizational changes, and probably to enter into several licensing agreements with different partners, which might be very risky depending on the nature of the business and intensity of competition. Usually, an industry with higher competition is also more risky in respect of finding an appropriate business partner.

The dissimilarity or intricacy in the product range and the type of technology used affect the overall complexity and difficulty of these processes. Usually, a special managerial team has to be established. The outlicensing approach may require developing new technology internally rather than by external cooperation. At the 
same time, external technology exploitation should be taken into consideration in the make-or-buy decisions on increasing particular technology competencies (Lichtenthaler, 2008). The primary trend is to link the processes of generating technologies or their improvement and exploitation of them. But this has to be based on systematic and systemic integration of internal R\&D activities and external technology exploitation based on very good strategic management. For example, not only Lucent but also other companies accentuate the great importance of integrated technology management. Under these circumstances, it is required to analyse corporate strategic technology plans by means of large-scale surveys and appropriate case studies (Lichtenthaler, 2008).

An OI strategy is not only about effective $\mathrm{R} \& \mathrm{D}$ exploitation and a number of external links, but also about the overall attitude of technology management to innovation and changes in general (Pontiskoiski and Asakawa, 2009). Each company wants to have an inimitable product/technology or service so as to obtain a greater competitive advantage on the market. However, if we take a look for example at Boeing's shift away from a highly centralized R\&D and logistics to a clear OI strategy where the supply and R\&D partners (based on very good relationships) have created many effective subsystems, we can conclude that this is a certain kind of common "Nash strategy", where everybody does what is best for themselves, but also for the other partners. This may be the best way to succeed also with an OI strategy in a highly risky environment.

In this context, the specific form of how to manage uncertainty and ambiguity of the external environment, especially associated with new open business development or open innovation, is to make small sequential irreversible investments in various forms called real options. These usually consist of option creation and option exercise. The option creation is the first investment that is about to create options for further investment/option exercise. The real option reasoning (especially interconnected with the open-innovation strategy) may be one of the main tools for risk reduction in the current times. Creating options through so-called learning investment, joining a R\&D consortium, establishing specific research agreements, or usage of seed capital ventures etc., can all be appropriate forms of investment in highly risky environments, especially in the first phase of an open innovation process. If the uncertainty drops to an appropriate level, then a company may enter into equity alliances, JVs, or outright acquisitions (Van de Vrande et al., 2006). An open innovation strategy may enhance the upward potential of new venturing and mitigate different risks as well as improve the learning potential of a company. Thus, real option reasoning may have significant implications for the absorptive capacity of the company (Vanhaverbeke et al., 2008).

Some successful factors for OI strategy:

- Open innovation processes must be based on constant business analyses, iterative long-term planning and systematic inter-organizational learning (Holmqvist, 2003) and collaborative know-how creation.

- It is necessary to summarize what resources and capabilities will be required for an open innovation approach before determining the strategy.

- Innovation and effective changes must be deep-rooted in culture and every activity in the company. 
- Product innovation can be performed effectively also with existing technology.

- Technology innovation must not affect overall financial stability of the company.

- Appropriate marketing, selection and retaining of key stakeholders, and covering fixed costs of the cooperation as much as possible are usually beneficial (Chesbrough and Appleyard, 2007).

- Disclosed knowledge must be transformed into the higher value of a product or technology as soon as possible.

- Innovation needs not to be only something revolutionary, but it is necessary to take advantage of many small organizational improvements in existing technology.

- Although technology innovation brings the change, it is necessary to take this change positively with a view of final benefits.

- New knowledge also has to bring new attitudes and a new better culture for the company (Pontiskoiski and Asakawa, 2009), but also a better attitude towards stakeholders, especially customers.

- Careful assessment of the internal culture, the kind and character of the intellectual property (IP), a possible competitive impact has to be set as a part of the strategy (Munsch, 2009).

- Wider external cooperation with a much larger range of stakeholders should create more complex solutions than only an internal attitude towards innovation affected by internal know-how, culture and possibilities.

- The business shift to an OI strategy with more active partnerships should considerably increase the complexity of the innovation system. Based on experience, we can say that the complexity of solutions increases exponentially with every new partner (Munsch, 2009). However, many examples confirm that partnership with foreign companies or investors and a foreign culture may also be a source of much discontent.

- The OI strategy should also help communicate tacit knowledge more intensively inside the company and within business partners.

- Business management and strategy dynamics have to be interconnected with the dynamics of the environment, taking into account all priorities, visions and champions.

- Speed and quality of logistics can be improved by better exploiting market opportunities.

- Risks and uncertainties are diversified and a greater market scale should be achieved by wider cooperation (Munsch, 2009). But again, by applying an OI strategy, the company has to consider business opportunities and threats both from the current perspective and from the expected view of the future.

An OI strategy is usually applied based on a partnership of two or more parties. These integrate their know-how, capacities and resources in order to create a new technology, product or to join a new market together. For these objectives, new capacities and know-how are developed. What is usually changed is the structural nature of the production value chain in these companies. For example, the PC industry changed in the 1980s (in the time of the global PC revolution) from vertically integrated organizations, where the main company (usually 
the producer) controlled almost every component of the value chain, to modular subsystems. In such a sub-systemic approach, each component (microprocessors, operating systems, disks, etc.) has had a wider interdependence and might have been interchanged if non-effective (Munsch, 2009). In this approach, a partial management and control process are shifted to partners that brings the lower costs for the main company. It is especially important to choose partners properly here, as well as to think about their possible substitution if necessary.

The contract and its subparts and all the dimensions have to be properly considered. The contract should define clear business relationships, responsibilities, new IP ownership, its application, exclusivity, resource commitment, timing, project and its termination conditions and other related factors (Munsch, 2009). Aspects that may be particularly fuzzy are the actual technological approach, patent potential and scope of future business opportunities. Each party has to be aware of the contract in detail even before the agreement. How to share results and inventions coming from mutual cooperation? Is it necessary to also define which fields of application will be exclusive/nonexclusive and for whom, what the sublicensing rights will be and how to share the new benefits? The partnership may require new organization and staff as well as new investment to bring the common innovation to the market. Each partner (especially in the US) entering into such a contract should be informed about the Sarbanes-Oxley Act (especially its section 401a), which defines and specifies the financial conditions of the partnership and informs about possible barriers and risks that this OI approach may bring.

\section{Some barriers to OI strategy:}

- There is "no need for change" in the innovation system despite the changing environment.

- The company does not really examine its innovation potential, market opportunities or customer wishes.

- Strategy, culture and management style keep down creativity and innovativeness.

- Innovation processes are not supported by stakeholders because of inadequate knowledge about proposed changes or their non-involvement in these processes.

- Innovation processes are not planned adequately, plans are not implemented and processes are not regularly controlled.

- Management does not wish to disclose its $R \& D$ intellectual property at all; especially SME may have fears to disclose their non-patented core know-how.

- Intellectual property (IP) protection does not properly protect the company's know-how or innovation.

- A specific company does not know how to commercialize its innovation (Pontiskoiski and Asakawa, 2009).

- Diversity of participants' backgrounds in open innovation teams become a source of misapprehension, leakage of information and know-how, diverging objectives and values, or loss of control over the process (Tidd and Bessant, 2009).

- External technology exploitation results in strengthening competitors by improper agreements or disclosure of relevant know-how.

- There is one dominant monopoly or a few larger companies that "close" the market. 
- Legislative is too restricted, judicature is non-flexible, or there are shortages in the legislative norms.

\section{Key questions and basic forms of an open technology innovation strategy}

It is known that every manager has their own specific objectives, rules, patterns, values, assumptions, and biases. At the managerial level, business requirements and personal predispositions affect the managerial style, but it is also affected by internal business culture, history and actual shareholders' requirements. Those with the strongest competences usually affect others. Over time, people usually accept this source of attitudes and change their own values. They also tend to take information mostly from these sources. This is called the dominant logic (Pontiskoiski and Asakawa, 2009). This is some kind of common "bounded rationality phenomenon" that can be very risky for a static institution over a long period of time because of constantly changing external conditions. The management style has to be flexible. It is exactly for these dynamics that the external exploitation of technologies has increasingly become a trend in the recent years. Each manager should take into consideration these key questions before applying their own OI strategy.

Key questions for an OI strategy:

- What is our current and expected market position and economic results?

- Who are our current and potential stakeholders, especially customers, suppliers or investors?

- How our $R \& D$ is performed and financed?

- How is our product innovation commercialized?

- What is our production and technology strategy?

- Do we really wish to disclose part of our product and technology know-how?

- How can this know-how be commercialized and how fast?

- What risks do we undertake by this disclosure?

- What are the internal and external barriers to the open innovation strategy?

- What is our perceived business attitude to the OI strategy?

- What are the possible forms of open business cooperation in our industry or region?

- What is the price of patent rights (patent infringement)?

- How to share IP among business partners?

- What competitive advantage should be created and for how long?

- What final and non-financial outcomes do we expect from open technology cooperation?

There are many formal and informal issues regarding the forms and ways of performing an OI strategy. The main ones include technology transfer, outsourcing, co-development agreements, designer contracts, business alliances, research and business clusters, patent licensing, etc. (see Figure 1). 


\section{Figure 1}

Main forms of Ol strategies based on organizational autonomy, time of new technology adoption and risk taking

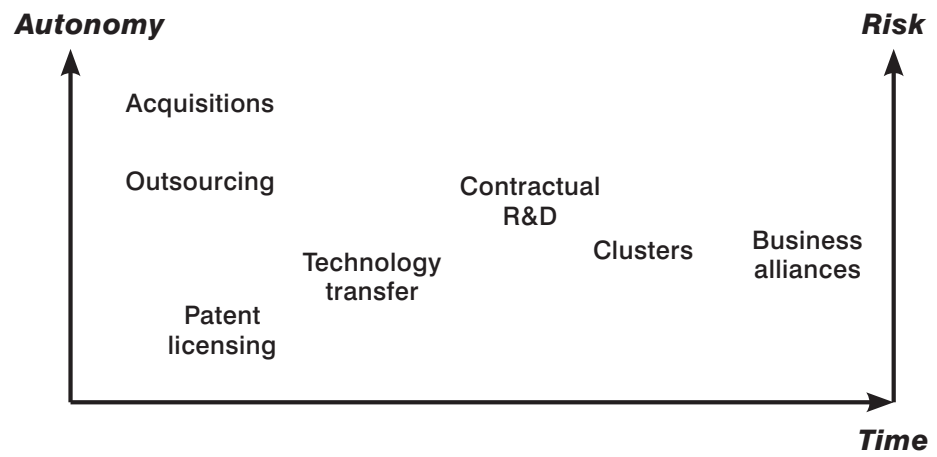

Source: Own compilation.

This figure differentiates the forms of OI strategies based on organizational autonomy, time of new technology adoption and risk taking by choosing one of the variants. Based on this taxonomy, we can say that the highest autonomy is associated with acquisitions, but they also pose the greatest risk because of the full responsibility and competence for the technology acquired. The longest time of new technology adoption belongs to business alliances because of the necessity to harmonize mutual activities among partners as well as to create functional organization, but the main benefit is the risk being diversified among different stakeholders. Patent licensing (without technology transfer) is more specific to the non-autonomy of business activities, but it brings leverage of risks too and a shorter time of innovation adoption. Dual licensing may also exist: a public free version license and a commercial version license. This is called "versioning of innovation", especially applied in the SW industry (Chesbrough and Appleyard, 2007). For instance, open-source SW includes practices that have produced much of the innovation in the US in recent years (CFID, 2006). Reasonable help in these circumstances is provided by Creative Commons, a non-profit organization that provides free licenses and other legal tools to mark creative work with the freedom of the creator, so that others can share and commercially use specific innovations (Creative Commons, 2010). This is very helpful especially for SME, which lack funds for obtaining their own patent or a specific license.

If we consider possible forms of OI strategies based on the dissimilarity in technologies applied, market dissimilarity and product dissimilarity (see Figure 2), then is it obvious that the greatest dissimilarity of all these factors belongs to business alliances. The smallest dissimilarity is characteristic for acquisitions, patent licensing and technology transfer. As another example, an outsourcing company usually operates in a different market but can use comparable technologies and offer a comparable product range as the submitter. 


\section{Figure 2}

\section{Main forms of OI strategies based on dissimilarity of technologies, markets and products}

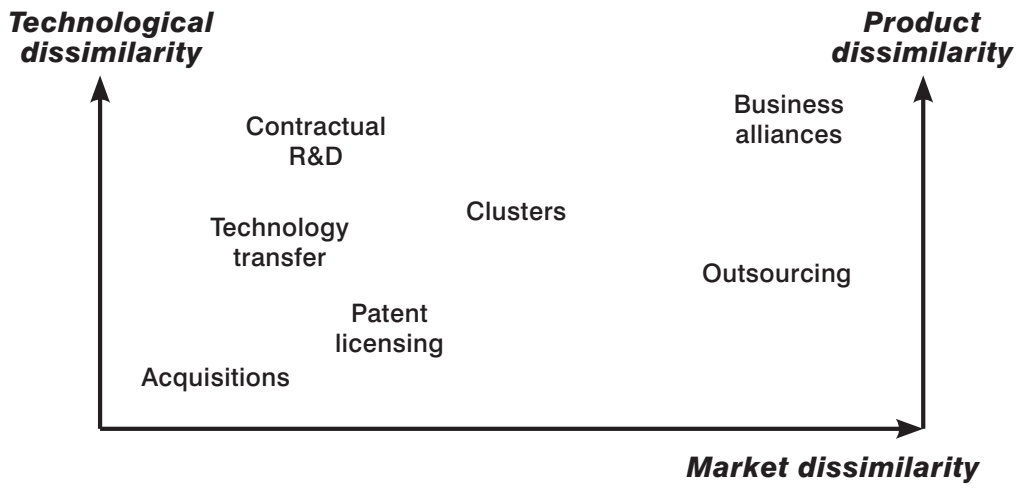

Source: Own compilation.

Each of these forms of OI strategies has to be adapted to the current and expected business possibilities. Considerable help in this context is also provided by a great number of OI supportive websites such as NineSigma, InnoCentive, the InnovationXchange, Planet Eureka, etc. (Jusko, 2009).

If we compare OI strategies in three selected companies (Apple, Nintendo, Nokia), we can notice that there is no universal pattern for these open activities. All these companies operate in different however allied areas of ICT and more or less in the gaming industry too. They might be expected to have almost identical innovation strategies, but their innovation systems are completely different. Apple secures the best ideas for innovation flowing into the company by hiring the best talents usually already from schools and with strong intra-institutional culture towards its own brand. This is more or less a classical internal attitude to innovativeness, but the company also outsources some parts of its R\&D; this enables the company to focus on its core activities, such as user interface and marketing. Therefore, this might be called only a limited open innovation strategy.

Nintendo bases its product innovation on offering customers unique experience by complete differentiation from other competitors. The Nintendo products are aimed to connect current as well as expected customer wishes (by intensive marketing analyses) into a new higher value of own products. This is more or less an advanced classical innovation strategy.

Nokia disperses its R\&D all over the world and systematically identifies opportunities in its venture organizations as well as external trends and changes from the perspective of technology, business and users. These activities enable the company to identify potential indicators of a change very early (Vanhaverbeke et al., 2008). Another objective is to secure the real efficiency of these activities (Pontiskoiski and Asakawa, 2009). The company performs its $R \& D$ based on the main corporate strategy, but this is adapted and influenced by local environments of its branches. These 
branches cooperate with many different local $R \& D$ companies and suppliers in their regions. This approach might be called a fully open innovation strategy. Within these three cases, Nokia applies the OI approach in the widest range. We can conclude that each company has chosen its own innovation strategy from these basic (see Figure 3).

\section{Figure 3}

Basic typology of innovation strategies

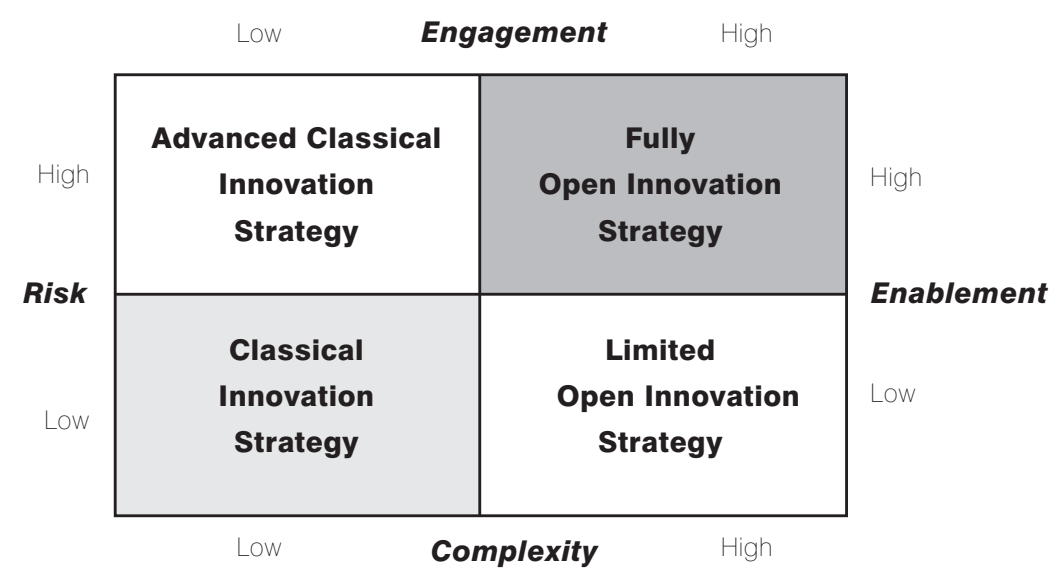

Source: Own design.

Many companies choose an OI strategy in order to engage a wider innovation community to find out more complex solutions to more complex challenges in their environment, but this is not sufficient on its own. This strategy enables many companies to find better knowledge, but they fail at enabling to integrate knowledge successfully into their own organization (Chesbrough, 2003). The processes are inadequately prepared for new solutions, people are not educated and skilled enough, budgets are not established for new expenditures, suppliers and investors are not found, technologies do not exist or marketing does not know how to support new solutions, etc. This is all because managers do not set strategic objectives and processes properly and no functional organization for the OI strategy exists.

If a company chooses an OI strategy to engage a broader community in an innovation process in a less risky environment, this can bring more complex innovative solutions. If the strategy is less complex and hence the company secures lower engagement concerning internal and external capacities for realization of the innovation, then we can only speak about an advanced classical innovation strategy. If this open strategy is not properly implemented, it may result in a lack of understanding and "non-performance" of more complex open solutions. Then we can only speak about a limited OI strategy. If a company outsources some parts of its R\&D, but does not cooperate actively with other stakeholders in related activities (financing, marketing, obtaining of patent protection, etc.) then again this can still only be called a limited OI strategy. In this context, it might be interesting to compare the overall attitudes to the classical innovation strategy and the fully open innovation strategy (see Table 2). 
Table 2

Comparison of classical and open innovation strategies

\begin{tabular}{|c|c|c|}
\hline & Classical innovation strategy & Fully open innovation strategy \\
\hline $\begin{array}{l}\text { Overall } \\
\text { attitude to } \\
\text { innovation }\end{array}$ & $\begin{array}{l}\text { Nobody should know what we are innovating, } \\
\text { how and from which resources. We need } \\
\text { individual unique IP. }\end{array}$ & $\begin{array}{l}\text { Different partners are invited to participate } \\
\text { in innovation and related processes. We } \\
\text { can share IP, but also profit from others' IP. }\end{array}$ \\
\hline $\begin{array}{l}\text { Attitude to } \\
\text { business } \\
\text { improvement }\end{array}$ & $\begin{array}{l}\text { Spending more on internal R\&D will improve our } \\
\text { processes, products, market positions and even } \\
\text { protect our know-how. }\end{array}$ & $\begin{array}{l}\text { Different partners bring different know- } \\
\text { how, resources and capabilities and thus } \\
\text { improve our processes, products, market } \\
\text { positions and consequently economic } \\
\text { results. }\end{array}$ \\
\hline $\begin{array}{l}\text { Attitude to } \\
\text { maximizing } \\
\text { profit }\end{array}$ & First-to-patent $=$ highest profit & First-to-market $=$ highest profit \\
\hline $\begin{array}{l}\text { Attitude } \\
\text { to } R \& D\end{array}$ & $\begin{array}{l}\text { The more R\&D staff we have the more possible it } \\
\text { is to close our innovative gaps. }\end{array}$ & $\begin{array}{l}\text { The less staff we have engaged in R\&D } \\
\text { the more complex and more effective } \\
\text { solutions can be obtained from external } \\
\text { sources. }\end{array}$ \\
\hline $\begin{array}{l}\text { Attitude } \\
\text { to risk }\end{array}$ & $\begin{array}{l}\text { If we do not disclose our know-how, we will not } \\
\text { risk. }\end{array}$ & $\begin{array}{l}\text { We build new capacities to increase our } \\
\text { ability to take a new risk. }\end{array}$ \\
\hline $\begin{array}{l}\text { Attitude } \\
\text { to market }\end{array}$ & The best products for a market. & $\begin{array}{l}\text { The best business model for } \\
\text { a company and a market. }\end{array}$ \\
\hline
\end{tabular}

Source: Own design.

What distinguishes an OI strategy in general from other forms of cooperation is mainly collaborative learning and know-how creation. This process usually consists of four stages. The first one includes externalization and sharing of information, experience, know-how and expectations among different group members. Then, interpretation and analyses of information gathered from the first stage follow. The third stage is called negotiation and revision of own ways of thinking in order to create a mutual sense of understanding. The last one is combination and creation of new know-how, ideas or forming common attitudes. The competencies required for such collaborative learning (especially inter-organizational) in OI teams must be equalized with actual challenges and risks such as "being committed, being dependent or being overextended". However, each member of such open cooperation should be adequately able to manage its membership, to work in the team, to control and coordinate itself, and externalize its know-how without superfluous risk (Chatenier et al., 2008).

\section{Global innovation networks and the open technology innovation strategy}

Openness and innovativeness - global innovation networks (GINs) - play an increasingly important role for businesses in the current age of almost unpredictable complex globalisation processes. GINs bring together researchers, developers and other stakeholders around the globe and significantly affect national, regional and individual innovation performance and trends. These may be also called Eco-systems or Eco-networks because of their own self-structure usually concentrated around large global corporations in specific industries or around chief international institutions 
(OECD, UNIDO, OPEC, etc.). Such ecosystems should link international, regional or individual innovation systems. What are their main specifics?

Main specifics of OI partnerships within global innovation networks:

- The key reason for R\&D placement to GINs is the existence of large and thriving markets, existence of qualified human resources, especially engineers, designers and researchers, and existence of suppliers and other related capacities (finance, insurance, marketing, etc.).

- Companies favour business partners that are geographically nearby, but will enter into collaborations with geographically distant partners too if they can offer significant advantages such as strong market demand or product-technology excellence.

- Integration into clusters and R\&D networks becomes very important but integration across fields and countries also requires other complex capacities. Overall innovativeness depends on interconnections in a network and on quality of relations and know-how inside.

- Companies try to balance their R\&D intentions and possible investment in their regions with efforts to be more and more open in order to develop appropriate absorptive capacities in their business.

- IP disclosure broadly requires new managerial competences affected by a local business situation, culture and legislative.

- The first place as innovation partners belong to suppliers and customers, while universities and researchers are the main sources of know-how for innovation.

- Global corporations innovate more openly than small firms, but again, it is necessary to remember that global corporations have their own intra-business networks. Generally, global corporations cooperate in innovation four times more intensively than other firms (OECD, 2008).

- There is no significant difference between the manufacturing sector and services regarding application of OI strategies, but industries such as logistics, pharmaceuticals and ICT typically apply the OI approach more (OECD, 2008).

- The OI strategy has to be interconnected with training and supporting education that are required due to the necessity to work in new fields, disciplines or under new conditions.

- The open innovation strategy also requires a change in public relations and marketing because these open activities are usually more observed by public.

- Usually there is more support for product- and technology innovation and less for non-technology (organizational, financial, managerial) innovation or different forms of user-driven innovation.

- While the OI strategy requires more support of services, public support is more focused on manufacturing companies. And public sources support the supply side of innovation more than building market demand for innovation (OECD, 2008).

- The spread of the OI approach also requires support of national R\&D policies and programmes, which have to follow global trends in order to ensure benefits through higher reciprocity, cross-border spillovers or cost-sharing agreements. National $\mathrm{R} \& \mathrm{D}$ support programmes have to be disclosed and communicated properly. 
- International institutions play an important role in these processes as a strong knowledge and financial supportive base also so as to identify policy implications and develop next-generation innovation policies and best practices (OECD, 2008).

If we take a look at the types of cooperation in global innovation networks through the degree of innovation, spatial spread and dissimilarities of participative companies, then we can divide these kinds of cooperation into four main categories (see Figure 4).

\section{Figure 4}

Main types of cooperation in global innovation networks

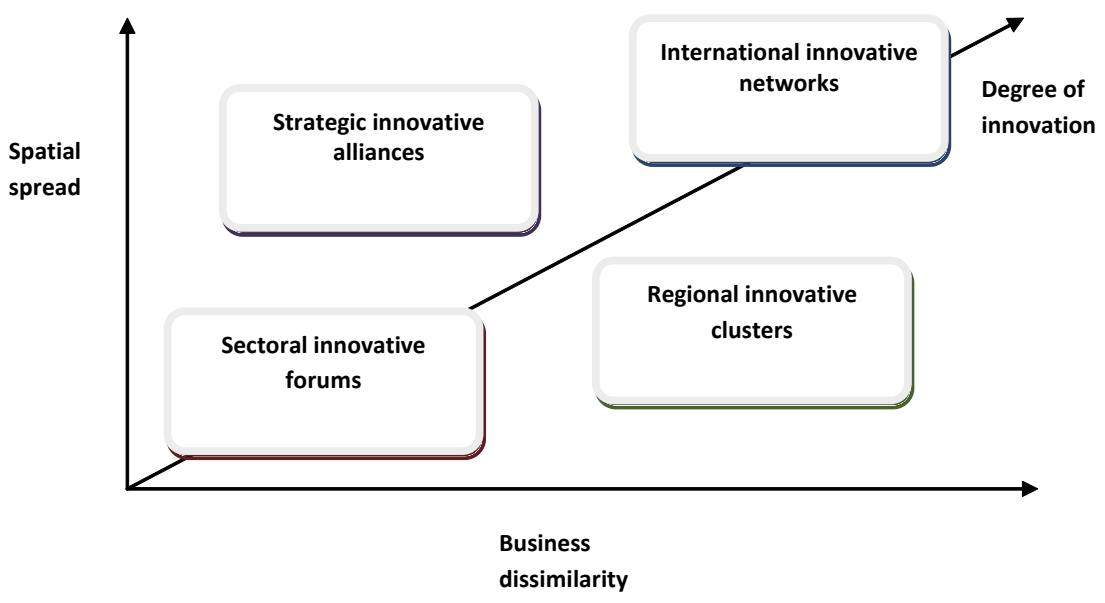

Source: Own compilation based on Tidd, 2006.

Sectoral innovative forums are focused on facilitation of innovation development by systematic linking of researchers, academics, technologists, designers, managers, marketers, policy makers and others to share different knowledge and improve the complexity of innovative solutions. These may be performed as a regional foresight project. Alternatively, for example, the Construction Innovation Forum (CIF) in the USA is an international, non-profit institution formed to recognize and encourage innovation improving quality, efficiency and effectiveness of construction (CIF, 2010).

Regional innovative clusters link various industries and scientific R\&D. Successful regional clusters stimulate competition and create synergic cooperation among stakeholders in these clusters. These clusters enable knowledge exchange and generation of critical capabilities that are mutually supportive to other stakeholders. Geographical proximity of companies in such a cluster enables speeding up R\&D projects and supporting the creation of new enterprises. Examples include Silicon Valley, the Boston cluster, ICT regional clusters in Finland, Ireland, Denmark, Spain, the Netherlands, and hundreds of others.

The main outcome of strategic innovative alliances is an increasing number of more complex innovations and new patents as well as new innovative enterprises. Each company that joins such an alliance also enters a number of direct and indirect interrelationships. In a highly clustered network, such firms are densely connected to each 
other. Clustering enables sharing information and know-how more precisely and quickly because of direct links between companies and thus to improve further cooperation among them. For example, the European Sustainable Energy Innovation Alliance is an association of leading innovation organisations in the field of sustainable energy with the main objective to improve common innovation and implement more sustainable energy systems in Europe as well as in the world (ESEIA, 2010).

International innovative networks are forms of large business cooperation that enable developing and selling new products and services collaboratively with different business partners, which is highly advantageous for reducing the risks connected with innovation failures. These diverse networks provide opportunities for integrating and effectively improving knowledge across geographically dispersed units as well as supporting small enterprises. For example, the Enterprise Europe Network consists of 600 companies across 40 countries and offers complex innovation and technological services provided by the former IRC Network (Spain). In addition, it provides information on the EU legislation and funding opportunities and assists in finding suitable partners and developing new R\&D capacities (EEN, 2009).

\section{Conclusions}

An OI strategy means a shift from the traditional internal attitude, where all innovation originates inside a company, to an advanced, more open attitude also called an "external" or "networked" innovation approach (Chesbrough, 2003), in which both internal and external sources are combined to create a higher, more complex value added of innovation and related activities. Other benefits include early involvement in new technology or business opportunities, extended flexibility, delayed higher financial commitment, reducing upward loses by early exit or delayed exit if necessary (Vanhaverbeke et al., 2008). The best way to sustain an OI strategy is at the very base of the traditional business strategy because a company has to find a more complex solution/strategy to profit from this more complex and risky cooperation. This article has identified some main drivers, key questions, successful factors, but also barriers and sub-strategies to open technology innovation.

Among the main drivers, the best ideas for innovation usually come from outside a company, e.g., from customers and broader expert discussion that is not usually part of an internal management process. Due to the business effectiveness, companies usually perform their core activities around their main business and outsource what somebody else can do better and more effectively. Companies also increasingly use new forms of searching for inventions far beyond their organizational boundaries, e.g., through patent and bibliometric analyses, new social networking technologies, the Internet, etc.

The management should know the chief strengths and weaknesses of its own company based on real market opportunities and threats. Then it is necessary to find a balance between these two areas. Innovation processes have to be based on constant external and internal business analyses and iterative long-term planning/foresight. Then it is necessary to summarize what resources and capabilities will be required for an open innovation approach before determining the strategy. Innovation and effective changes also have to be deeply rooted in the company's culture and all activity. Problems may appear if there is "no need to change" an innovation system despite the changing 
environment if a company does not really examine its innovation potential, market opportunities or customer wishes, if its strategy, culture and management style keep people's creativity and innovativeness low, or if innovation processes are not supported by stakeholders because of an inadequate knowledge database about proposed changes or their non-involvement in these processes.

Open innovation strategies are ever more applied in independent casual innovation, while systemic innovation requires a more appropriate mix of open and closed classical innovation strategies because systemic innovation usually needs additional related innovation to achieve cardinal benefits. Many industries such as chemicals, health, agriculture and steel are characterised by a longer life cycle, strong protection of IP and a systemic nature of technology innovation development (Chesbrough, 2006). In general, an OI strategy is more applicable for industries with a shorter life cycle such as ICT, logistics, electronics, etc. It may imply that companies with an OI strategy innovate more intensively. As has already been mentioned, an OI strategy encompasses wider processes regarding cost-effective penetration to new markets and cultures, sourcing external technology or product development, systemic organizing of know-how creation, etc.

The degree of openness of an innovation strategy differs depending on factors such as importance of technology, autonomy of new organization, risk taking, time for new/ innovative technology adoption, enablement of the main business strategy, dissimilarity in technologies, products or markets, engagement of people cooperating, or complexity of solutions (OECD, 2008). Based on these factors, in addition to the classical closed innovation strategy and the fully open innovation strategy, we can also distinguish an advanced classical innovation strategy and a limited open innovation strategy. In every strategy, key competencies (technology analyses, finance, marketing) are usually performed internally.

The possibility of abusing IP is considered to be the main risk to global innovation networks. Key know-how may be disclosed to external partners who may later become competitors to their own former organization. Closer cooperation with external partners may lead to uncertainty about benefits of technology cooperation. If this is a cooperation between companies of different sizes, SMEs (small and medium enterprises) in particular face greater risks because of limited resources and capabilities regarding IP issues (OECD, 2008). Effective technology management is crucial for finding appropriate external partners, identifying necessary external know-how or supportive capacities, and particularly for more complex open technology innovative solutions.

\section{References}

BUGHIN, J.; CHUI, M.; JOHNSON, B. 2008. The next step in open innovation. McKinsey Quarterly [On-line]. June 2008, [cit. 2009-09-15]. www.mckinseyquarterly.com. ISSN 0047-5394.

CIF 2010. About us. The Construction Innovation Forum [On-line]. February 2010, [cit. 2010-02-17]. www.cif.org/ about-us.php.

CREATIVE COMMONS 2010. About. Creative commons project [On-line]. February 2010, [cit. 2010-02-15]. http://creativecommons.org/about/.

CHATENIER, E.; VERSTEgEN, J.; BIEMANS, H.; MULDER, M. 2008. Towards a competence profile for inter-organizational learning in open innovation teams. Paper presented at the Academy of human resource development International research conference in Panama City [On-line]. February 2008, [cit. 2009-09-25]. www.eric.ed.gov/ERICWebPortal/contentdelivery/ servlet/ERICServlet?accno=ED501606. 
CED. 2006. Open standards, open sources, and open innovation: Harnessing the benefits of openness. A Report by the Digital Connections Council of the Committee for Economic Development USA, April 2006, s. 1-44. ISBN 0-87186-182-8.

CHESBROUGH, H. 2003. Open Innovation: The New Imperative for Creating and Profiting from Technology. Boston : Harvard Business School Press, 2003. ISBN-10: 1578518377.

CHESBRouGH, H. 2006. Open Business Models: How to Thrive in the New Innovation Landscape. Boston : Harvard Business School Press, 2006. ISBN-10: 1422104273.

CHESBROUGH, H.; APPLEYARD, M. 2007. Open innovation and strategy. California Management Review. 2007, vol. 50, no. 1, s. 57-74. ISSN 0008-1256.

CHESBROUGH, H.; GARMAN, A. R. 2009. How open innovation can help you cope in lean times. Harvard business review. Dec. 2009, s. 68-76. ISSN 0017-8012.

EEN. 2009. Enterprise Europe Network: Business Support on Your Doorstep, Brussels : EC [On-line]. August 2009, [cit. 2009-08-12]. www.enterprise-europe-network.ec.europa.eu/index_en.htm.

ESEIA. 2010. About. The European sustainable energy innovation alliance. [On-line]. February 2010, [cit. 2010-02-15]. http://eseia.eu/.

GROENVELD, P. 1997. Roadmapping integrates business and technology. Research-Technology Management. 1997, vol. 40, no. 5, s. 48-55. ISSN 0895-6308.

HOLMQVIST, M. 2003. A Dynamic Model of Intra-and Interorganizational Learning. Organization Studies. 2003, vol. 24, no. 1, s. 95-123. ISSN 0170-8406.

JUSKO, B. 2009. Open innovation tools. Industry week. 2009, September, s. 52-53, ISSN 0039-0895.

LICHTENTHALTER, U. 2008. Integrated Roadmaps for Open Innovation. Research -Technology Management. 2008, vol. 51, no. 3, May - June, s. 45-49. ISSN 0895-6308.

MUNSCH, K. 2009. Open Model Innovation. Research-Technology Management. 2009, vol. 52, no. 3, May-June, s. 48-52. ISSN 0895-6308.

OECD. 2008. Open Innovation in Global Networks. ISBN 978-92-64-04767-9.

PONTISKOISKI, E.; ASAKAWA, K. 2009. Overcoming Barriers to Open Innovation at Apple, Nintendo and Nokia. Proceedings of World Academy of Science, Engineering and Technology. 2009, vol. 41, May, s. 372-377. ISSN 2070-3740.

TIDD, J. 2006. A Review of Innovation Models [Discussion paper No 1]. London : Tanaka Business School, Imperial College, 2006.

TIDD, J.; BESSANT, J. 2009. Managing Innovation: Integrating Technological, Market and Organizational Change. 4th ed. Chichester : Wiley. ISBN 978-0-470-99810-6.

VAN DE VRANDE, V.; LEMMENS, C.; VANHAVERBEKE, W. 2006. Choosing Governance Modes for External Technology Sourcing. R\&D Management. 2006, vol. 36, no. 3, s. 347-363, ISSN 0033-6807.

VANHAVERBEKE, W.; VARESKA, V. V.; CHESBROUGH, H. 2008. Understanding the advantages of open innovation practices in corporate venturing in terms of real options. Creativity and innovation management. 2008, vol. 17, no. 4, s. 251-257. ISSN 0963-1690.

WINCENT, J.; ANOKHIN, S.; BOTER, H. 2009. Network board continuity and effectiveness of open innovation in Swedish strategic small-firm networks. R\&D Management. 2009, vol. 39, no. 1, s. 55-66. ISSN 0033-6807.

\section{INTRODUCTION TO OPEN TECHNOLOGY INNOVATION STRATEGIES}

Abstract: An open technology innovation strategy can be characterised as a proactive combination of intra-institutional strengths and external opportunities of a market in order to create more complex technology solutions by exploiting capacities, capabilities and know-how of another institution (another company, university, research institution, etc.). This strategy may also postulate new market, industry, region, or culture penetration and concurrently has to require new business models. The main research questions of this article are stated as follows: What are the main drivers, key barriers, successful factors, main questions and basic typology of Ol strategies in general? The issue of global innovation networks is outlined at the end of the article. The research was based on an extensive literature review, discussion with experts and several case studies (Apple, Nintendo, Nokia, etc.).

Keywords: Open innovation, Open innovation strategy, Technology, Effectiveness

JEL Classification: 031,032 